\title{
景観認識における意識の連関と生成に関する基礎的研究*
}

\section{A Basic Study on Interrelations and Productions of Images in Landscape Cognition*}

\author{
萩下敬雄 $* *$ - 山田圭二郎*** ・ 中村良夫**** \\ By Takao HAGISHITA** • Keijiro YAMADA ${ }^{* * *} \cdot$ Yoshio NAKAMURA ${ }^{* * * *}$
}

\section{1. はじめに}

\section{(1) 既往研究・文献}

景観（環境）の認知に関わる既往研究，文献は数多 く存在する.ここで, それらのうち本研究との関連か ら見て重要な既往研究, 文献 (Lynch ${ }^{1)}$, Cullen $^{2)}$, Alexander ${ }^{3)}$, 清水 ${ }^{4)}$, 柳川 ${ }^{5)}$ らの研究) を挙げる.

Lynchは，ある都市に対して人々が抱く共通なイメ ージ (パブリックイメージ) を研究し, imageability, legibilityといった評価概念から都市のイメージを構成 する5要素を抽出し, 各要素の特徵(identitiy), それに 対して人々の抱く意味(meaning), 要素の相互関係 (structure)の重要性を指摘した. Lynchがここで問題 にしたのは, 空間体験の基本単位となる個々の具体的 場面（視覚像）ではなく，それらが統合されて出来上 がった認知地図と言う広範な空間の全体像であった.

一方, Cullenは，都市を関係の集積・集合体である と考え, 関係を取り結ぶ際の技法（「環境の技法」） の重要性を主張した. 彼の言う「関係」はLynchのそ れとは異なり, 現場体験での個々の場面における要素 の関係や人の動きにより起こる継起的，連続的な場面 の関係（シークエンス）であった．彼の関心は場面場 面での具体的経験の方であり視点や視線とその移動が 重要視されている. 彼の言う関係の集積としての都市 の全体像がどのように形成されるかについては言及し ていない.

Alexanderは, 我々の住む環境に生ずるある問題と それに対する解決策を一つの「パタン」により示し， 都市全体からディテールに至る複数の異なるパタン同 士を連関させることによって都市や建築を設計する方 法論を提示した. Alexanderのパタン・ランゲージは 設計に関わる実用的な視点であり, イメージの分析に

*キーワーズ : 景観, イメージ分析

**学生員, 京都大学大学院工学研究科 土木システム工学専攻

（干606-8501 京都市左京区吉田本町 TEL075-753-4788, FAX075-753-4789)

***正員, 修士(工学), 京都大学大学院工学研究科 同専攻 ****フエエロー, 工博, 京都大学大学院工学研究科 同専攻
は直接関心は向けられていないが，彼が「一つのシー クエンス（パタンの連関）では全体を完全に把握する ことはできない，後に続くシークエンスを見ていくう ちにネットワークの全容がつかめる」（括弧内筆者） と述べるこの個別のパタンと全体の関係は, 場面から 全体像に至る都市のイメージ形成過程と類似する.

清水は空間における人間活動の中で形成されるイメ 一ジに焦点を当て, 物理的環境とイメージ構造との関 係を分析した. 基本的な清水の研究の視点は, Lynch の言う要素の相互関係(structure)を抽出することに あったが，多数の被験者を対象にしたアンケートによ り要素の想起順位を調査し, 要素から要素への意識の 流れが全体としてセミラティス構造を持つことを明ら かにした点はAlexanderの研究と関連する.

柳川は, Lynchが重要性を指摘しながら分析の対象 から敢えて外したmeaningに着目し，社会的，文化的 に認知された空間である名所の図会を対象に，図会に 描かれた場面から受ける空間感覚的意味とその連関を 分析した。それにより，ある場面の意味を補強する形 で他の場面や文字情報が複数連関するという環境の認 識構造を明らかにしたが, それによって得られる全体 像については言及していない.

\section{(2) 研究の位置付けと目的}

我々の景観認識は, Lynchの認知地図に代表される 全体像のイメージとは別に，それとは異なるCullenの 言うような実体験による個々の具体的視覚像やそれに 附随する意味からなる多様で豊かな無数の断片的イメ ージのダイナミックな展開がある.このような断片的 イメージとその連関は必ずしもパブリックイメージに は結びつかない個人に強く依存するものとも考えられ るが, このような個人の連想の発展, その潜在的可能 性をまず許容し，その連関構造を正確に把握すること は, 全体像の形成過程を把握する上でも非常に重要で あると考えられる. また, 景観イメージに関する研究 は基本的に操作論的景観論の立場にあり，イメージ論 は計画・設計論への応用がその目的にある. しかし, 景観デザインは対象としての景観の操作によるデザイ ンだけではなく, 認識の枠組みのデザインによる新た な風景の解読法の提示によっても可能であると考えら 
れる. 以上のような視点から断片的なイメージや意味 の連関構造そのものに焦点を当てた研究は希少であ る. 柳川の研究はこの意味で興味深い研究であるが, 図会を対象にした分析にとどまり，実際に人のイメー ジを対象とした分析は行っていない.

そこで本研究では, 既往研究の清水寺を対象に景 観意識の連関構造を抽出することを目的とする. 具体 的には，2章では自由連想法を用いたアンケートの分 析により連関構造を抽出した. 3章では2章で得られた 連関パタンの一部をより詳細に把握するために, 地誌 メディア（ガイドブック）を用いた連関構造の分析を 行った。研究対象地域を図-1に示した.

本研究の調査・分析手法により清水寺という場所の 全体像が把握可能であるか，またその手法が妥当であ るかは明確に出来なかったため本研究では扱わない.

\section{2. 自由連想法による連関構造の抽出}

\section{（1）分析の枠組み-自由連想法-}

本章では自由連想法を用いたアンケートを実施し， 研究対象地において被験者が撮影した写真とそれに対 する記述の分析から, 主として具体的視覚像としての 景観意識の連関構造を抽出した。

被験者は京都大学の学生 4 名を対象とした．被験者 数が少ないのは本研究の趣旨が多数の被験者から得ら れるパブリックイメージの抽出を目的としておらず, 異なる連関パタンを数多く抽出するためには，いたず らに被験者の数を増やすよりも少数の被験者から得ら れた結果を可能な限り詳細に分析する方法を採用する 方が研究の趣旨に鑑みて妥当と判断したためである.

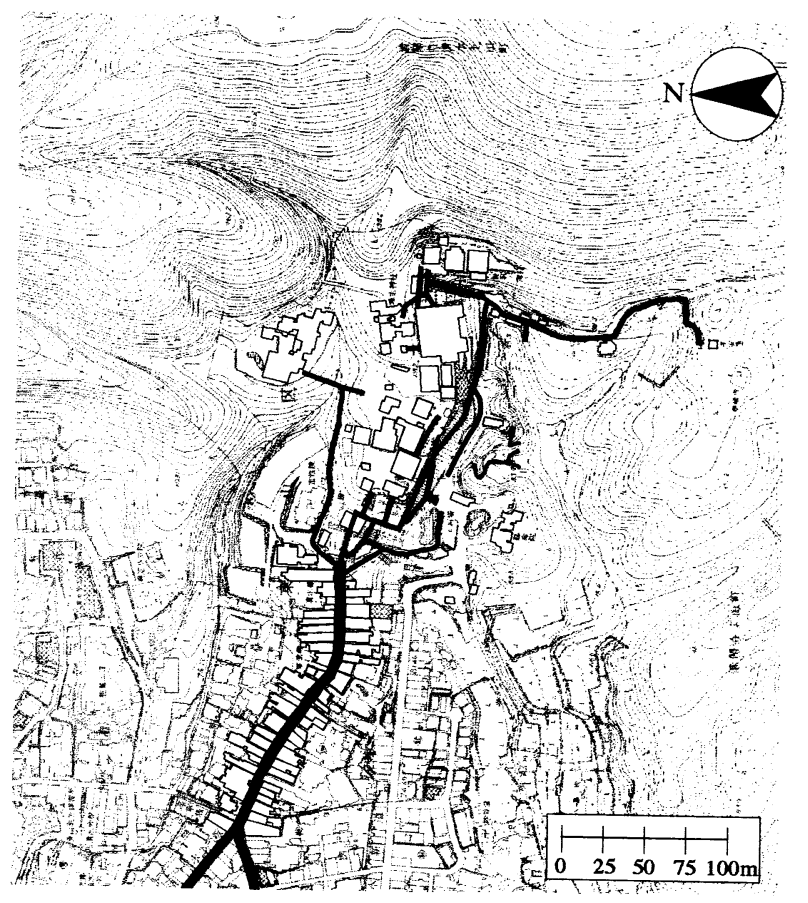

図-1 研究対象地域（清水寺）
アンケート及び分析の手順を以下に記す。

I ) 被験者が対象地に赴き撮影を行う.

撮影した位置と方向は地図上に記入してもらうが, 被験者に対して撮影対象, 位置, 撮影枚数, 撮影方法 等の制限は一切設けない. ただし, カメラはズーム機 能付きのカメラを使用する.

II）自由連想法によるアンケートを行う.

アンケートは質問形式とはせず，現像された写真を 被験者に見せ, 被験者はその写真に関する事柄，ある いはその写真から連想した事柄を自由に記述する。

III）被験者の記述をもとに写真を分析する.

被験者の意識は, 撮影時, 被験者の撮影する景観や その中の要素に対して向けられていることを前提とし た.ただし連関構造の抽出には被験者の記述のある马 真のみを用いる.

一枚の写真の中の一部分あるいは一要素に関する記 述であると明確に判断できる記述があれば，被験者は 全体への意識からその部分あるいは要素へ意識を集中 させたと判断して，その記述をもとに写真を分割し全 体と部分とを連関させる.

また, 被験者の記述をもとに異なる写真間の連関構 造を抽出する.

IV）以上から得られた連関構造を分類, 整理する.

\section{(2) 連関構造}

前節に記した手順による分析の結果, 被験者の意識 の連関構造として単純SEQUENCE型，LANDMARK 型, PAN型, CROSS-REFERENCE型, 見返り型, ZOOM型, 引用型, 連想型の9パタンが抽出された （図-2参照）。これらの連関構造は以下の 3 種類に大 別できる.

\section{I ) 現地提供像連関}

現地で得られた視覚像（撮影された写真）の連関.

II ）意味追加連関

現地で得られた視覚像に関連する意味を付加する連 関で, 画像と文字情報（テキスト）による連関. 引用 型がこれに当たる.

\section{III) 連想型連関}

現地で得られた視覚像の中の対象物（場）の色, 形 等の特性に関連して, 別の画像や文字情報を連想し結 び付ける連関. 連想型がこれに当たる.

上記の現地提供像連関は, 主に意識, 視点（場）と 対象（場）の関係から更に7つの連関パタンに分類さ れた. 以下に上記の連関の具体的説明，例を示す．な お，連関パタンに関する図中内の $\square$ (四角) で囲んだ 文章は, 被験者の記述を表す。
i) 単純SEQUENCE型
視点の動きに伴い継起的に起こる現地での景観体験 と同様の順で想起される意識（視覚像）の連関で, 最 


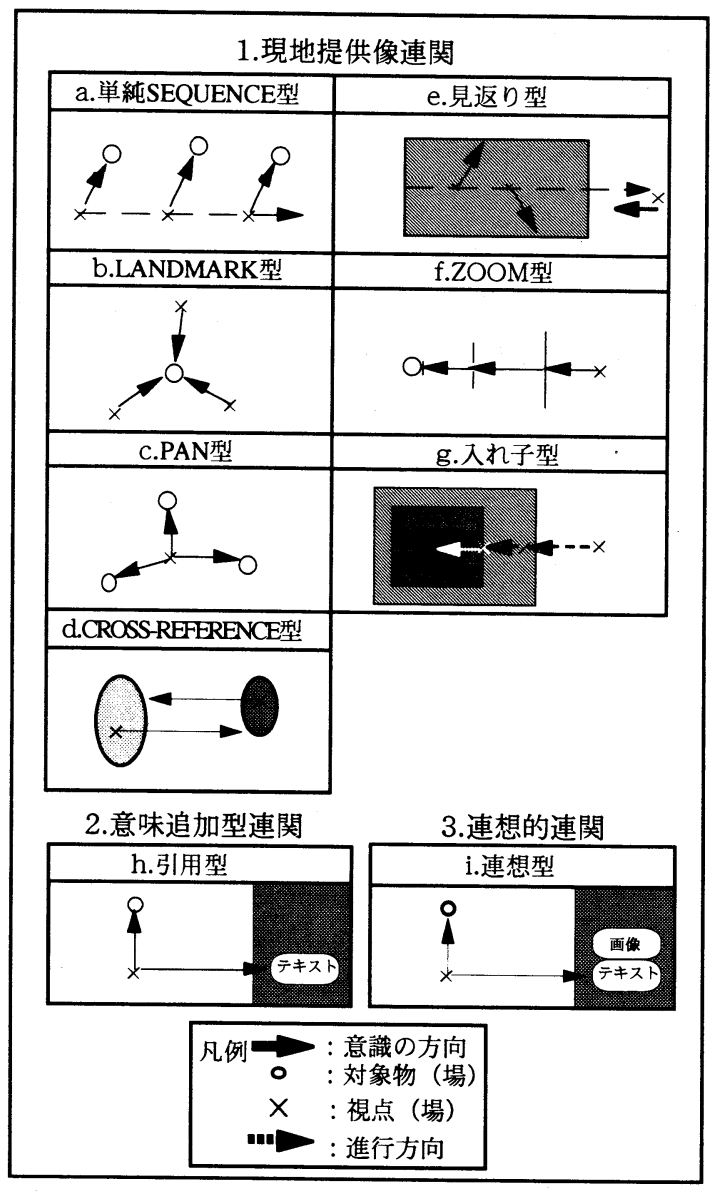

図-2 9つの連関檴造

も一般的な型であった。

ii ) LANDMARK型（図-3参照)

対象は同じ対象を意識しているが，視点が変化し， 異なる視点から得られた同じ対象に対する視覚像が連 関する型.

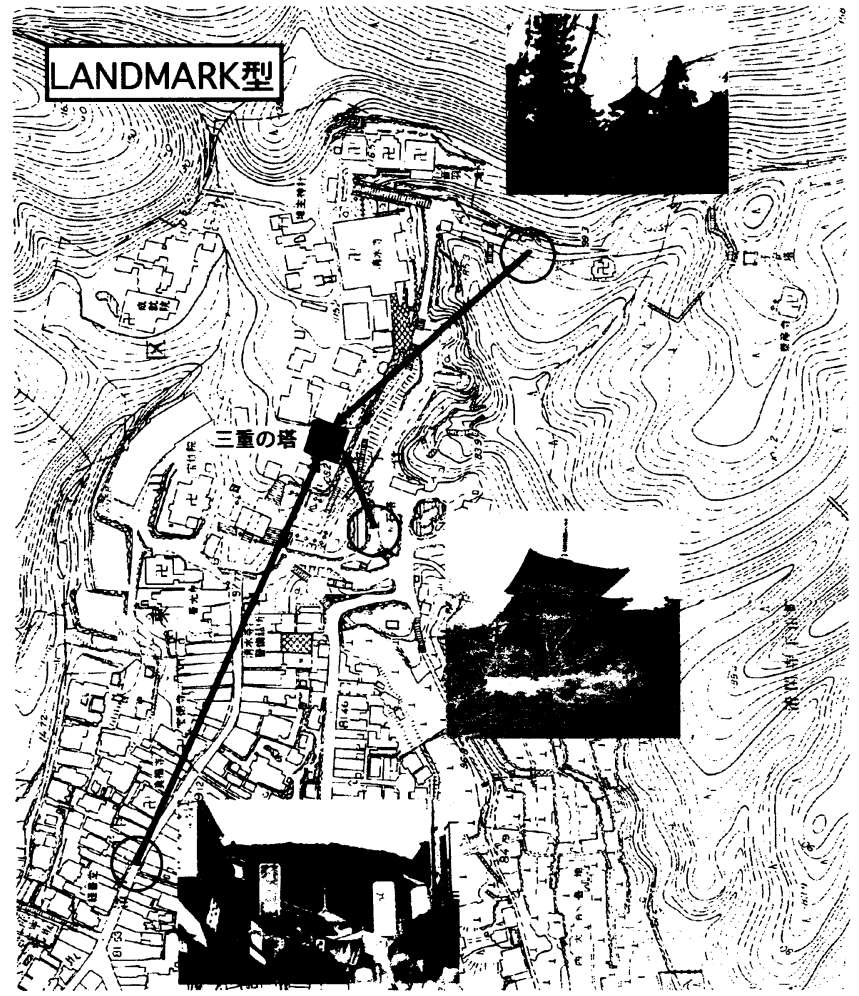

図-3 LANDMARK型

\section{iii）PAN型（図-4参照）}

被験者の視点は固定されているが, 視線が多方向に 移り, 同じ視点から見た様々な対象物, 視対象へ意識 が連関する型.

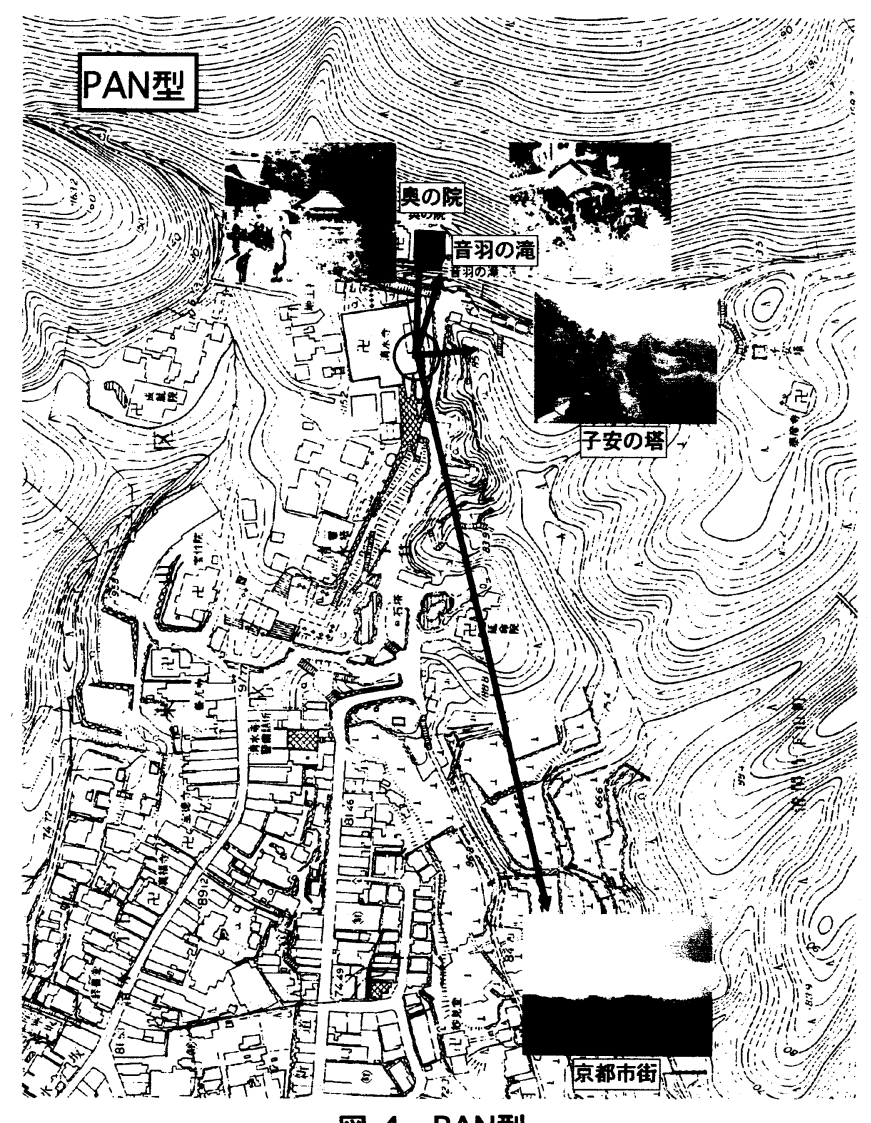

図-4 PAN型

iv） CROSS-REFERENCE型（図-5参照）

一つの視点（場）から見た対象（場）への意識 （視覚像）が, 次にはその対象（場）を視点（場）と して見た元の視点（場）への意識に連関する型.つま り, 視点（場）と視対象（場）を意識の中で逆転させ る相互参照型の連関である.

具体的には清水寺本堂舞台と奥の院との間で, 視点 （場）と対象（場）との関係が意識上逆転して連関す る例があった。

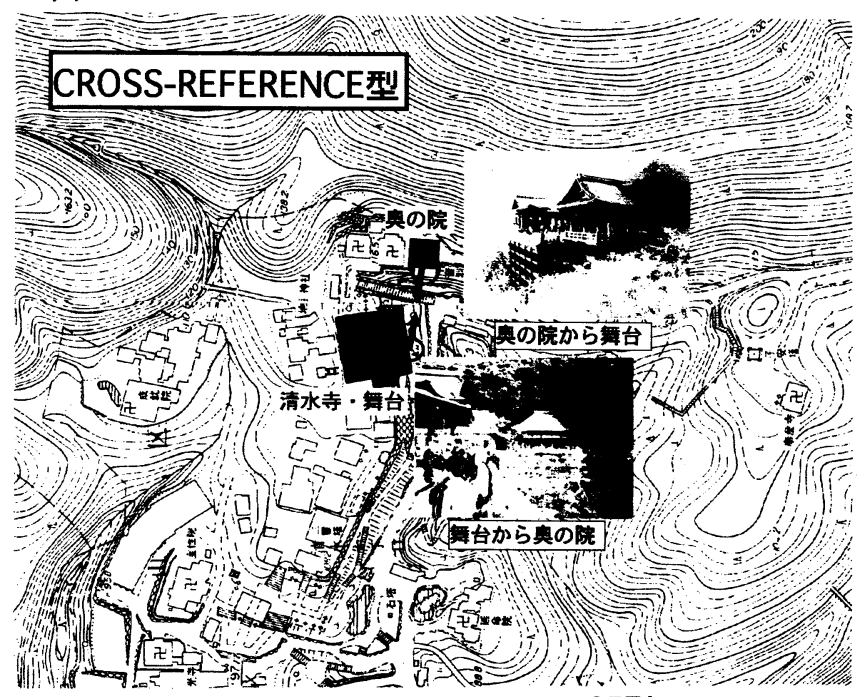

図-5 CROSS-REFERENCE型 
v）見返り型

被験者がある統一したテーマを持ったエリアを抜け て振り返った時に, そのエリアに全体としての統一性 を意識し連関する型. 意識が進行方向に対し正反対の 向きに動く.

具体的には, 清水坂の画像から, 坂を登り切った後 に振り返って清水坂を眺めた画像に意識が連関する, 紅葉の下を通り抜けた後に「紅葉の道を通った」と振 り返る例等があった。

vi）ZOOM型

視点場, 視線, 対象物（対象場）は変わらないが, 写真の機能で言うズームイン, ズームアウトのよう に，全体から部分あるいは部分から全体へと意識する 視覚像が拡大・縮小する型.

具体的には三重塔に向かって意識が絞り込まれてい く例, 門や植栽等が作るフレームを通してそのフレー ムの中へ意識が絞り込まれていく例, 人の群がるとこ ろへ意識が絞り込まれていく例等があった.

vii）入れ子型

ZOOM型に似て大きく捉えれば対象は変わらないと 言えるが, 意識の中で期待を持ち, 被験者の意識が対 象の外部から内部に向かって移行することによって連 関する型.

具体的には, 店の店構えの像 (意識) から, 店内で 陳列された商品へ意識が移行する例, 本堂の外構から 本堂内部に安置された仏像へ意識が移行する例等が あった.

viii) 引用型（図-6参照）

前述の II）意味追加連関である.

具体的には, 清水寺の舞台の画像から「清水の舞台 から飛び降りる」という舞台にまつわる慣用句を引用 的に意識する例等があった.

ix）連想型

前述のIII）連想型連関である.この連関ではある場 所（ここでは清水寺）で得られる視覚像に限らず, 全

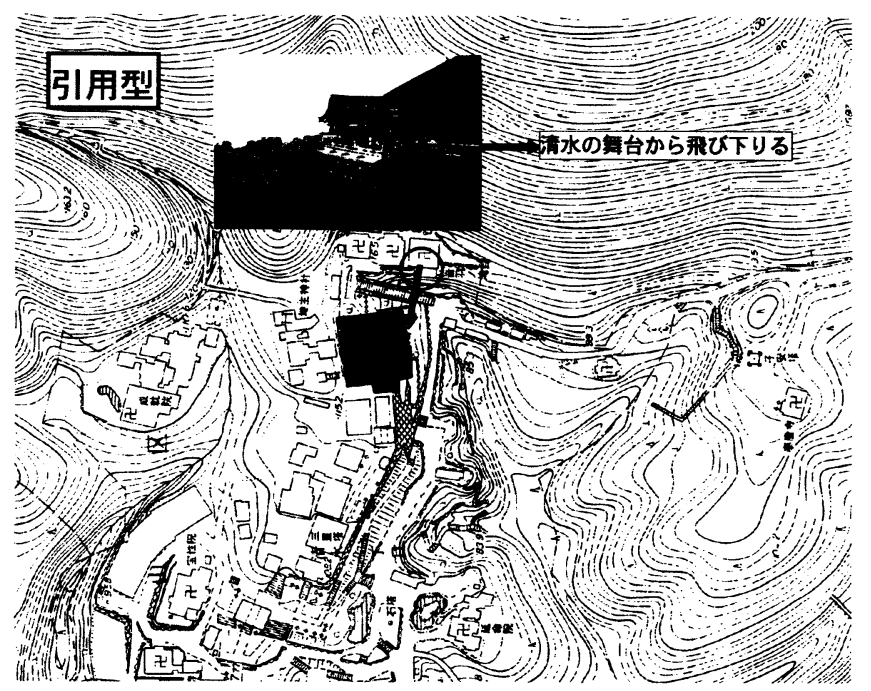

図-6 引用型
く別の場所に関わる意識に連関する可能性がある.

具体的には, 三重塔の朱色から下鴨神社や奈良の薬 師寺を意識する例があった.

(3) 考察

現地提供像連関は, 主に視点 (場) と対象 (場) の 間の意識上の関係に起因する断片的な視覚像の連関で あり,この連関構造「自体」は特に社会・文化的価値 に基づくその場所の意味を伴わない, どの場所でも共 通に起こり得る普遍的な連関構造と言える. 一方, 意 味追加連関（引用型）, 連想型連関は, 視覚体験によ り得られた画像に様々な価值観を付加し, その場所の 体験をより深めるものと捉えられる.

実際の景観体験は先に述べた通り, 視点の移動, 首 や眼球の運動による, 時間的に連続な継起的視覚体験 であるが, LANDMARK型, CROSS-REFERENCE型 に見られたように意識上では時間的, 空間的な飛躍を 伴って連関していた. また, 本研究では一回の現地体 験により得られた写真とアンケートを基に分析を行っ たが，実際には複数回の体験の統合が連関しイメージ が形成されていると考えられる. 引用型や連想型では その場所の歴史等に関連して更に大きな時間の飛躍が 起こり得, また全く違う外部の場所への空間的飛躍を 伴う連関も起こり得る.

視野 $60 \%$ コーン説に代表されるような視知覚特性と は異なり, 意識上での視野 (意識野) は, ZOOM型や 入れ子型のようなダイナミックなスケールや空間の飛 躍による連関が成立する。

\section{3．地誌メディアに見る連関構造}

\section{（1）分析の枠組み}

2章では被験者の撮影した写真と自由連想法による 記述の分析から, 主として具体的視覚像としての意識 の連関構造を抽出した. 従って, 2章での被験者の記 述は主として各視覚像の連関構造を抽出するための手 段として用いた。本章ではテキストも視覚像と同様に 景観認識を構成するもの（要素の集合）と考え, 画像 と文章（テキスト）により複合的に構成された表現媒 体である地誌メディア（ガイドブック）の分析から, 画像とテキストからなる連関の全体構造を明らかにす ることを目的とする.

以下に本章の分析手順を示す.

I ） 4 冊のガイドブック ${ }^{6778899}$ を用い, 文章の意味内容 が一塊であると考えられる部分に文章を分割する.

II）複数回引用されている一つのキーワードについて それを含む意味内容の塊(ここではこれを「小テキス 卜」と呼ぶ）を全て抜き出す。言語の最小単位である 単語のレベルまで文章を分解して連関構造を調べる.

III）III）で抜き出された各小テキストの内部あるいは 


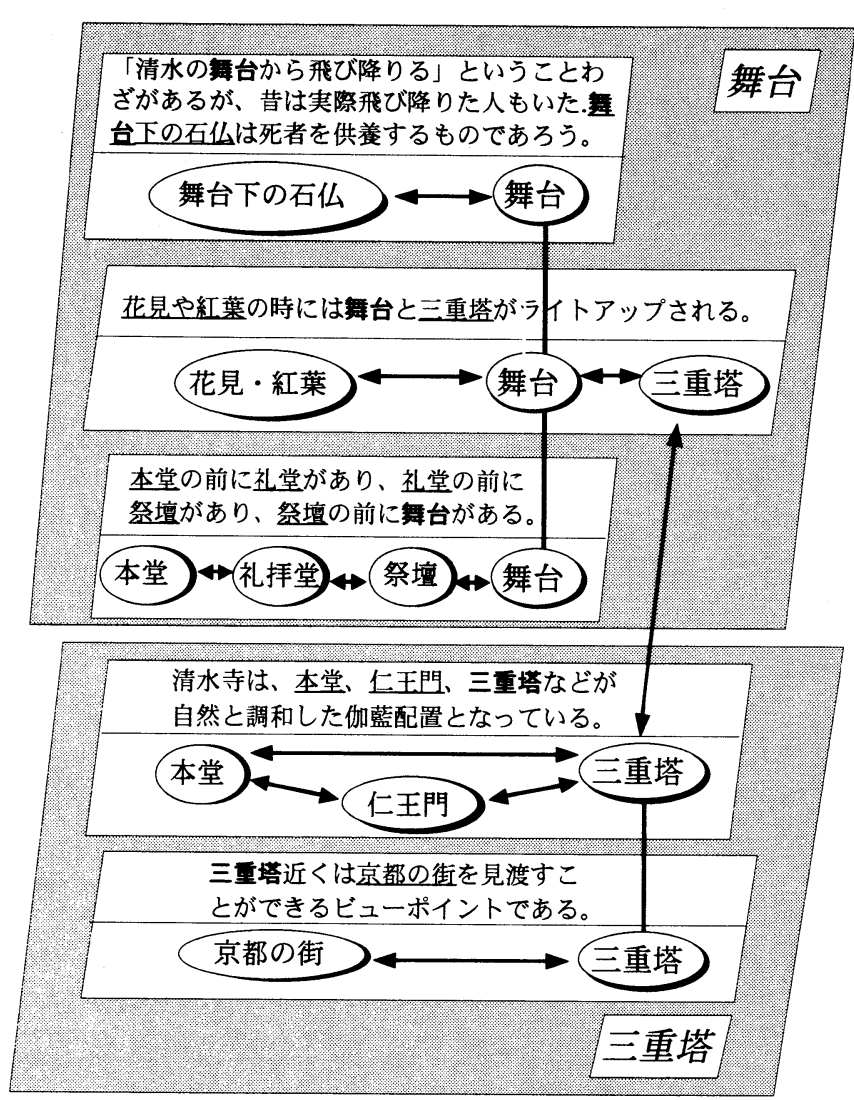

図-7＼cjkstart地誌メディアの連関構造

小テキスト間の要素の連関を調べ，その要素をリンク （線図）を用いて構造化する.

IV）ＩI）他のキーワードについても同じょうに II）

IV）の手順を繰り返す.

\section{（2）連関構造}

「舞台」をキーワードとした小テキスト及び画像情 報は7箇所に存在した。 それらをその意味内容から分 類すると以下の通りであった。
i ）舞台に関連する歴史
ii ) 行事
iii）ことわざ
iv）建築の特徵・配置
v）ビューポイント（視点場からの眺望）
vi）地理的環境
vii) 写真

舞台と三重塔に関するテキストを，前節の分析手順 を用いて構造化した結果の一部を図-7に示した。この 図では写真については示されていないが，舞台や三重 塔という単語には当然その視覚像の認識があり,これ らの単語とそれに対応する写真とは連関していると考 えられる。

以上から，画像とテキストの複合体である地誌メデ ィアの連関構造とその全体構造が把握された.

\section{4. 認識モテルとしてのハイパーテキスト構造}

本章では，2章，3章で把握された画像とテキストの 連関により展開する人の景観認識を忠実に再現し得る モデルの構造として, ハイパーテキスト構造(Hypertext)の可能性について考察した.

（1）ハイパーテキストの定義

Nielsenによれば，ハイパーテキストは「全体のテ キストが部分的なテキストの塊（チャンクあるいは） 一ド）としてまとめられており，それぞれの塊間の結 合関係が定義されている. そして，それらのリンクを たどるためのメカニズムが提供されている．このよう な形態で与えられた非線形構造のデータの枠組み」 ${ }^{10)}$ と定義される.

（2）ハイパーテクスト構造の可能性

ハイパーテキストはコンピュータのWeb上で用いら れており，画像，テキスト，音声等の複合的媒体によ り構成される。この概念を用いた構造は, 言葉や画像 の断片の連関を非線形・多次元的に構成する. また， この枠組みの中では中心や入り口という概念は存在し ない.すべての断片がすべての連鎖関係の中の一つの 要素として取り扱われる. つまり, この構造は, 理想 的には無限な広がりを見せる多次元的な連鎖構造であ るといえる ${ }^{11)}$.これは本研究で把握された意識の連関 が個人に依存し，その始まりも連関の繋がりもパブ リックイメージのように一義的に決定できないことと 類似する. 上記のハイパーテキスト構造の概念を図-8 に示す。この図は，3章で示した画像とテキストの複 合媒体である地誌メディアの構造と非常によく似てい る(図-7参照).

以上のことから, 景観認識を忠実に再現し得るモデ ルの構造として, ハイパーテキスト構造の可能性の一 端が示され得ると考えられるが，これについては実際 にハイパーテキスト構造を適用することにより，より 詳細に検討する必要がある.

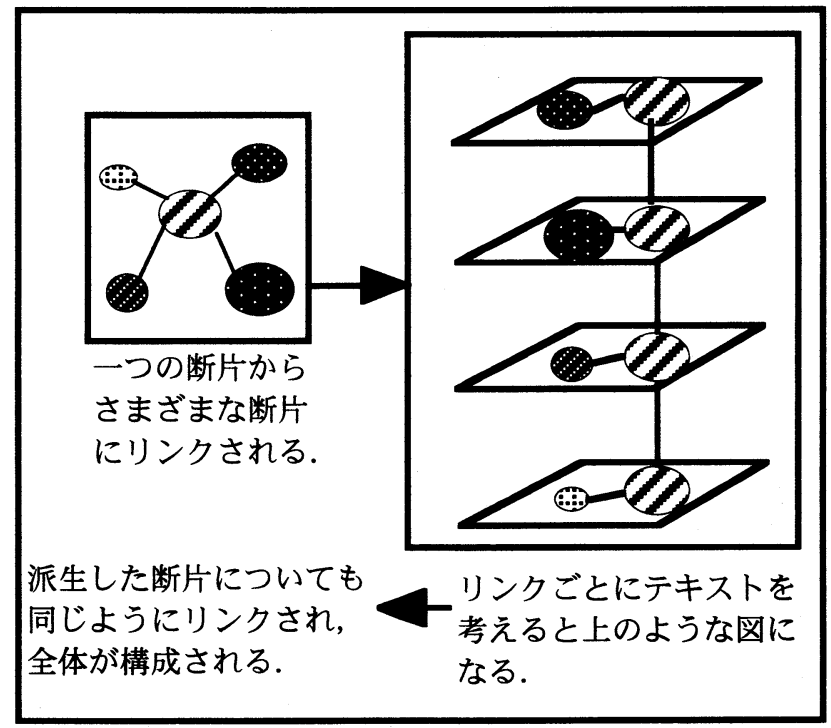

図-8 ハイパーテキスト概念モテル 


\section{5. 結論}

\section{(1) 研究の成果}

本研究から得られた成果を以下に示した.

I ) 自由連想法を用いたアンケートの分析の結果, 大 きく分けて 3 種類の連関構造（現地提供像連関, 意味 追加型連関, 連想的連関) が抽出された. 現地提供像 連関は, 更に細かく 7 種類（単純SEQUENCE型, LANDMARK型, PAN型, CROSS-REFERENCE 型, 見返り型, ZOOM型, 入れ子型）に分類すること ができた.

これらの連関構造の組み合わせにより，断片的な視 覚像やそれに付加される意味内容が多数連関し, ダイ ナミックで豊かな景観認識が展開すると考えられる.

II ）地誌メディアの分析から, 画像とテキストにより 複合的に構成される景観認識の連関の全体構造を把握 した.

III）Ｉ）ＩI）の連関構造を忠実に再現するモデル構造 として, ハイパーテキスト構造の可能性を指摘した.

\section{（2）今後の課題}

本研究は意識の連関構造とその組み合わせによって 構成される景観認識の全体の構造を明らかにした。し かし， ある場面の具体的視覚像や意味内容の集積から 成立する場所の全体像については明らかにしていな い. 本研究の視点から場所の全体像を提示するために はまず，4章でその可能性を示したハイパーテキスト 構造を実際に適用し, 景観認識を忠実に再現し得るモ デルとしての害用性を検証してみる必要があり, 今後 の課題として挙げられる.

風景は一つの物理的要素のみから構成されているの ではなく，スケールや距離の異なる様々な要素が入り
交じって構成されている. 従って, 限られた平面図, 立面図，パース図によるこれまでの空間表現とは異な るダイナミックな空間表現が可能なハイパーテキスト 構造は，この意味でも非常に有用であると考えられ る.

本研究は直接的に操作論的景観論に関わる立場では ない.しかし，ある連関パタンの持つ景観的効果や具 体的な空間設計の技法との関わりは分析してみる必要 があろう。

研究対象地を変えた更なる連関構造の分析が, 上記 の視点に共通する今後の課題として挙げられる.

\section{参考文献}

1)Lynch,K.:The Image of the City,MIT Press, 1960 2)G・カレン : タウンスケープ, 鹿島出版, 1975 3)C・アレクサンダー : パタン・ランゲージ, 鹿島出 版, 1983

4)志水英樹 : 街のイメージ構造, 技報堂出版, 1979

5)柳川正宏 : 複合表象としての都市景観に関する研 究，東工大修士論文， 1994

6)黑沢明夫 : 英文 日本絵解き事典 5 , JTB印刷, 1985

7)John,H.andPhyllis, G.M.:Kyoto-A Cultural Guide to Japan's Ancient Imperial City,Chrles E Tuttle Company, 1994

8)黒田敏夫 : 京都へ出かけよう, 昭文堂, 1998

9)日本の世界遺産エリアマップ，昭文堂， 1998 10)Jacob Nielsen : HYPER Text \& HYPER Media, HBJ出版, 1991

11)ジョージ・P・ランダウ : ハイパーテクスト-活字 とコンピュータが出会うとき-, ジャストシステム, 1996

\section{景観認識における意識の連関と生成に関する研究}

萩下敬雄 $* *$ ，山田圭二郎*** 中村良夫****

人々が抱いている景観認識に関わる既存研究・文献は数多く存在するが，その多くはパブリックな イメージに関する研究であり，そのようなイメージとは異なる断片的な視覚像の連関によるダイナミッ クな景観認識に着目した研究は少ない，本研究では，自由連想法を用いたアンケートを実施し，その分 析から視覚像や意味内容に関わる意識の連関構造を抽出した。 また，画像とテキストの複合媒体である 地誌メディアを用いた分析により，その連関構造と画像とテキストにより構成される全体構造を明らか にした. 更に, この構造をモデル化する構造として, ハイパーテキスト構造の可能性に言及した.

\section{A Basic Study on Interrelations and Productions of Images in Landscape Cognition}

by Takao HAGISHITA** Keijiro YAMADA*** Yosio NAKAMURA****

There are many studies about Images in landscape recognition. But they all considered the Images to be limited. But people have great variety of senses of value. So we suggest a new method to extract the images in landscape cognition named "free association method " in this study. Then, we suggest how to model the structure of the Interrelations of Images. 